\title{
Comparison of Antidiabetic Effects of Aqueous Extract of the Leaves and Fruits of Avicennia Marina in Streptozotocin-induced Diabetic Male Rats
}

\author{
Leila Kamaei*1(D), Davood Moghadamnia' ${ }^{2}$ \\ 1. Department of Biology, Kazerun Branch,Islamic Azad University. Kazerun, Iran. \\ 2. PhD of Animal Physiology, Young Researchers and Elite Club, Shiraz Branch, Azad University. Shiraz, Iran.
}

\begin{tabular}{ll}
\hline Article Info & A B S T R A C T \\
\hline Article type: & Background: \\
Original Article & In this study, the anti-diabetic effect of the extract of leaves and fruits of \\
\hline Article History: & Avicennia marina (A. marina) in streptozotocin (STZ)-induced diabetic male \\
Received: 09.02 .2019 & rats was investigated. \\
Accepted: 17.04 .2019 &
\end{tabular}

Accepted: 17.04.2019

* Corresponding author:
Leila Kamaei
Department of Biology, Kazerun
Branch,Islamic Azad University.
Kazerun, Iran.
E-mail: leila.kamaei97@gmail.com

E-mail: leila.kamaei97@gmail.com

\section{Methods:}

An experimental study was conducted on 45 adult male rats in 9 groups of 5 rats. The control group received normal food only. Other groups were made diabetic by injecting them with $60 \mathrm{mg} / \mathrm{kg}$ intraperitoneal STZ injection. Diabetic groups were: one Sham Group (STZ only), one Positive Diabetic Group (STZ $+0.5 \mathrm{ml}$ normal saline) and 6 experimental groups, treated with STZ plus 3 incremental doses $(30,60$ and $120 \mathrm{mg} / \mathrm{kg}$ ) of either leaves or fruits extract of A. marina for three consecutive days, using gavage method. 24 hours after the last extract administration, blood samples were taken from the rat hearts., the serum glucose and insulin levels were measured by glucose oxidase and ELISA methods, respectively, one week after the STZ injections and following 8-12 hours of fasting.

\section{Results:}

The extract of leaves and fruits of A. marina in all doses significantly decreased the serum glucose in diabetic rats compared to that in the Sham group. The extract of A. marina leaves at $30 \mathrm{mg} / \mathrm{kg}$ significantly increased the serum insulin level compared to that in Diabetic Sham Group. The extract of A. marina fruits at all doses significantly increased the serum insulin level in the Experimental Groups compared to the Sham Group $(\mathrm{P}<0.05)$.

\section{Conclusion:}

The extract of leaves and fruits of A. marina significantly reduced the serum glucose in STZ-induced diabetic rats.

Keywords:

Anti-Diabetic Effect; Avicennia Marina; Serum Glucose and Insulin; StreptozotocinInduced Diabetes.

How to cite this paper

Kamaei L, Moghadamnia D. Comparison of Antidiabetic Effects of Aqueous Extract of the Leaves and Fruits of Avicennia Marina in Streptozotocin-induced Diabetic Male Rats. Iran J toxicol. IJT 2019; (2):7-12

\section{INTRODUCTION}

Diabetes is a chronic, lifelong illness and a major endocrine disease, causing a significant decline in the insulin secretion by the pancreatic beta cells. It is characterized by metabolic disturbances and long-term complications in the eyes, kidneys, nervous system and blood vessels. It is associated with a wide disparity in the metabolism of carbohydrates, lipids and proteins (1). Mangrove forests are unique ecosystems in tropical and salt-resistant areas (ㅁ), located in the
Asian tidal zone between the land and sea. Mangroves are evergreen trees and shrubs from various families of plants (프).

Avicennia marina (A. marina) is a member of Acanthaceae family. The species have large, toothed and leathery oval leaves, small, pale yellow flowers and seedy greenish-gray to yellow oval fruits (ㄴ) $)$ The plant contains such compounds as flavonoids (ㅁ), glucoside (ㅁ), phenylpropanoid (ㄱ) and glucose. Also, it is rich in various phytotoxins including alkaloids and quinines ()ㅡ, carboxylic acids, betaine, choline (ㅁ) $)$ tannins, 
hydrocarbons, alcohol, sterol, fatty acids, tocopherol, ascorbic acid and saponins (10). However, no information is available about the active ingredients of the fruits. In traditional medicine, the bark and root of this plant are used to treat sexual dysfunction in humans and arrhythmia in rats $(\underline{11}, \underline{12})$. The seeds are edible, and in some countries they are consumed for food and pharmaceutical purposes. The seeds oil is used to treat stomach diseases and tumors ( $\underline{13})$. In India, the crushed unripe fruit is used as ointment to treat skin abscesses, and the fruit extract improves eye infections $(\underline{11}, \underline{14})$. It has been found that the butanolium extract of this plant, can inhibit the activity of microorganisms, such as fungi (15).

A study has shown that the administration of the extract of $A$. marina leaves improves symptoms of oxidative stress in the liver, reduces the hepatic enzymes and prevents the adverse effects of diabetes on the liver ( $\underline{16})$. In another study, the dose-dependent administration of the aqueous extract of $A$. marina increased the activity of antioxidant enzymes and decreased the lipid peroxidation in the ovarian tissue of diabetic rats (17).

Considering the diabetic side effects in people, it is important to investigate alternative ways to treat or prevent them. Treatment options that are currently available for diabetes, such as dietary regimens and oral hypoglycemic agents have their limitations. Medicinal plans are widely used, especially in Asian subcontinent for the treatment of diabetes mellitus. The World Health Organization has recommended plans for the investigation and application of medicinal plants to treat numerous diseases including diabetes. This study investigated the anti-diabetic effects of the aqueous extract of the leaves and fruits of $A$. marina in streptozotocin (STZ)-induced diabetic male rats.

\section{MATERIALS AND METHODS}

Animals: This study was carried out on 45 adult male rats weighing $130-170 \mathrm{~g}$. The animals were kept at $25^{\circ} \mathrm{C}$ under standard conditions at the Research Center of Ahwaz Jundishapur University of Medical Sciences. Moral considerations for animal used in research were observed according to the ethical guidelines of Ahwaz Jundishapur University of Medical Sciences. The animals had unrestricted access to prepared food and water. Ether, a mild anesthetic agent, was used to prevent animals from suffering when they were sacrificed to collect blood samples.

Preparation of Extract: The leaves and fruits of $A$. marina were collected from the beaches and estuaries around the city of Mahshahr and identified to be true $A$. marina samples by the botanical department of the Faculty of Agriculture, Shahid Chamran University of Ahwaz. The aqueous extract from the leaves and fruits of $A$. marina was prepared, using the maceration method as previously described (토).
The leaves and fruits of $A$. marina were rinsed and dried in the shade separately. The samples of leaves and fruits were powdered separately by an electric grinding mill. To prepare the aqueous extract, $5 \mathrm{ml}$ of the solvent was used per gram of powdered leaves or fruits. The mixture was stored at 15 to $20^{\circ} \mathrm{C}$ for 72 hours, after which the solution was filtered, using Wattman No. 1 paper filter, and was lyophilized under vacuum. The aqueous extract of the leaves from $100 \mathrm{~g}$ of the dry matter rendered $8.2 \mathrm{~g}$ of lyophilized pure extract. Similarly, 100 grams of the dried fruits produced 14 grams of the pure extract. The extracts were stored separately at refrigerator temperature.

Induced Diabetic Rats: To produce diabetic condition, an intraperitoneal injection $(60 \mathrm{mg} / \mathrm{kg}$ body weight) of STZ dissolved in $0.9 \%$ normal saline solution was used. In order to confirm the effects of STZ on the pancreatic beta cells, serum glucose concentrations were measured one week after the injection and under 8-12 hours of fasting, using a glucometer device. The criterion to confirm diabetes in animals was the serum glucose level to be above $250 \mathrm{mg} / \mathrm{dl}(\underline{19})$.

Animal Treatment: In this study, the rats were divided into 9 groups of 5 . The control group received normal food only. Diabetic groups consisted of Diabetic Sham (STZ only), Positive Diabetic (STZ followed by 0.5 cc normal saline), and 6 Experimental groups (STZ followed by extract gavage). After the diabetic condition was verified, the aqueous extract of leaves and fruits of A. marina at doses of 30, 60 and 120 $\mathrm{mg} / \mathrm{kg}$ was fed to the Experimental groups for three consecutive days by gavage method (19). The duration of the test and the doses of the extract were selected using methods from a previous study (20).

To collect blood serum, 24 hours after the last dose of the extract, blood samples from the heart of the animals were collected after 8-12 hours of fasting (21). All samples were taken at the same time in the morning, centrifuged and the serum collected for the determination of glucose by glucose oxidase assay. To measure the serum insulin levels, blood samples were stored in ice-cold test tubes for one-time, then stored at

$-20^{\circ} \mathrm{C}$ until the insulin analysis was performed, using ELISA method.

Statistical Method: For statistical analysis of the data from various groups, one way ANOVA and Tukey tests were performed, using SPSS program version 18. The statistical level of significance was set at $\mathrm{P}<0.05$.

\section{RESULTS}

Changes in Body Weights: There was a significant decrease in the rats' body weights in all groups except for the controls seven days after STZ administration to the rats compared to the corresponding data at baseline (Table 1). Three days after the administration of $A$. marina leaves or fruits extract, the overall body weights in the Experimental groups did not change significantly compared to the corresponding data 
before administering the extract. However, there was a slight gain in the body weight of the Experimental group that received $60 \mathrm{mg} / \mathrm{kg}$ of the leaf extract, compared to those noted for other Experimental groups (Table 1).

Changes in Serum Glucose: One week after the single STZ administration in rats, the results showed that the serum glucose increased significantly $(\mathrm{P}<0.05)$ in all groups compared to that of the controls (Table 2). The serum glucose levels for the Sham and Positive Diabetic groups increased by $228.63 \%$ and $232.21 \%$, respectively. The serum glucose levels for the Experimental groups were significantly higher, ranging from 131.4 to $169.4 \mathrm{mg} / \mathrm{dl}$ compared to that of the controls (89.4 mg/dl). However, the mean glucose level in the Experimental groups was $51.7 \%$ lower than that for the Sham group (293.8 $\mathrm{mg} / \mathrm{dl})$. There was no significant differences in the serum glucose levels among the Experimental groups or between the subgroups of leaf and fruit extracts $(\mathrm{P}<0.05)$.

Changes in Serum Insulin: As seen in Table 3, significant declines in the serum insulin levels occurred to varying degrees in all groups that received STZ treatment compared to that of the control $(\mathrm{P}<0.05)$. The most decreases $(-94.02 \%$ \& $-83.3 \%)$ in the serum insulin levels occurred in the Positive Diabetic and Sham groups, respectively. The declines in the serum insulin levels in the experimental groups were less pronounced than those documented for the Positive Diabetic and Sham groups. As seen in Table 3, the percent changes in the serum insulin levels in the Experimental groups ranged from $-78.9 \%$ to $+149 \%$, compared to that in the Sham Group $(\mathrm{P}<0.05)$.

Table 1: The effect of STZ and the extract of $A$. marina on the rats' body weight.

\begin{tabular}{|c|c|c|c|c|}
\hline Group & $\begin{array}{l}\text { Body Weight } \\
\text { At Baseline (g) }\end{array}$ & $\begin{array}{l}\text { Body Weight } \\
7 \text { Days After STZ Injection (g) }\end{array}$ & $\begin{array}{l}\text { Body Weight } \\
3 \text { Days After Extract Gavage (g) }\end{array}$ & $\begin{array}{l}\text { Change* } \\
(\%)\end{array}$ \\
\hline Control Group & $138.40 \pm 4.00$ & $138.40 \pm 4.00$ & $138.40 \pm 4.00$ & 0 \\
\hline $\begin{array}{l}\text { Sham Group } \\
\text { (STZ treatment only) }\end{array}$ & $132.20 \pm 8.49$ & $113.80 \pm 8.13$ & $113.80 \pm 8.13$ & 0 \\
\hline $\begin{array}{l}\text { Positive Diabetic: STZ + } \\
0.5 \mathrm{ml} \text { normal Saline }\end{array}$ & $162.00 \pm 3.34$ & $147.20 \pm 2.41$ & $139.00 \pm 3.42$ & -5.6 \\
\hline $\begin{array}{l}\text { Experimental 1: STZ + } \\
30 \mathrm{mg} / \mathrm{kg} \text {, leaf extract }\end{array}$ & $148.00 \pm 4.44$ & $125.20 \pm 3.02$ & $123.40 \pm 2.83$ & -1.5 \\
\hline $\begin{array}{l}\text { Experimental 2: STZ + } \\
60 \mathrm{mg} / \mathrm{kg} \text { leaf extract }\end{array}$ & $142.40 \pm 5.60$ & $124.40 \pm 5.22$ & $129.40 \pm 5.50$ & +4 \\
\hline $\begin{array}{l}\text { Experimental 3: STZ + } \\
120 \mathrm{mg} / \mathrm{kg} \text { leaf extract }\end{array}$ & $157.20 \pm 5.15$ & $140.40 \pm 5.91$ & $140.60 \pm 7.43$ & 0 \\
\hline $\begin{array}{l}\text { Experimental 4: STZ + } \\
30 \mathrm{mg} / \mathrm{kg} \text { fruit extract }\end{array}$ & $155.00 \pm 10.3$ & $132.60 \pm 10.17$ & $128.00 \pm 10.02$ & -3.5 \\
\hline $\begin{array}{l}\text { Experimental 5: STZ + } \\
60 \mathrm{mg} / \mathrm{kg} \text { fruit extract }\end{array}$ & $154.40 \pm 5.74$ & $132.40 \pm 8.72$ & $131.00 \pm 7.48$ & -1 \\
\hline $\begin{array}{l}\text { Experimental 6: STZ + } \\
120 \mathrm{mg} / \mathrm{kg} \text { fruit extract }\end{array}$ & $151.40 \pm 6.78$ & $130.20 \pm 6.12$ & $123.00 \pm 6.38$ & -5 \\
\hline
\end{tabular}

Table 2: Effect of the leaf and fruit extract of A. marina on the serum glucose levels in STZ-induced diabetic rats.

\begin{tabular}{lll}
\hline Group & Serum Glucose $(\mathrm{mg} / \mathrm{dl})$ & Change (\%) \\
\hline $\begin{array}{l}\text { Control Group } \\
\text { Sham Group } \\
\text { (STZ treatment only) }\end{array}$ & $89.40 \pm 5.19$ & 0 \\
$\begin{array}{l}\text { Positive Diabetic: STZ + } \\
0.5 \mathrm{ml} \text { normal Saline }\end{array}$ & $293.80 \pm 10.88$ & $+228.63^{*}$ \\
$\begin{array}{l}\text { Experimental 1: STZ + } \\
30 \mathrm{mg} / \mathrm{kg} \text {, leaf extract }\end{array}$ & $297.00 \pm 12.87$ & $+232.21^{*}$ \\
$\begin{array}{l}\text { Experimental 2: STZ + } \\
60 \mathrm{mg} / \mathrm{kg} \text { leaf extract }\end{array}$ & $144.40 \pm 8.81^{* *}$ & $-50.85^{* *}$ \\
$\begin{array}{l}\text { Experimental 3: STZ + } \\
120 \mathrm{mg} / \mathrm{kg} \text { leaf extract }\end{array}$ & $169.40 \pm 5.66^{* *}$ & $-42.34^{* *}$ \\
$\begin{array}{l}\text { Experimental 4: STZ + } \\
30 \mathrm{mg} / \mathrm{kg} \text { fruit extract } \\
\text { Experimental 5: STZ + }\end{array}$ & $131.40 \pm 2.97^{* *}$ & $-55.28^{* *}$ \\
$\begin{array}{l}\text { 60 mg/kg fruit extract } \\
\text { Experimental 6: STZ + } \\
120 \mathrm{mg} / \mathrm{kg} \text { fruit extract }\end{array}$ & $134.40 \pm 5.33^{* *}$ & $-54.26^{* *}$ \\
\hline
\end{tabular}

$120 \mathrm{mg} / \mathrm{kg}$ fruit extract

*Significant difference with the control group $(\mathrm{P}<0.05)$.

** Significant difference with the Sham Group $(\mathrm{P}<0.05)$. 
Table 3: Effect of the leaf and fruit extract of A. marina on the serum insulin levels in STZ-induced diabetic rats.

\begin{tabular}{|c|c|c|}
\hline Group & Serum Insulin $(\mathrm{mlU} / \mathrm{ml})$ & Change (\%) \\
\hline Control Group & $3.51 \pm 0.40$ & 0 \\
\hline $\begin{array}{l}\text { Sham Group } \\
\text { (STZ treatment only) }\end{array}$ & $0.57 \pm 0.14$ & $-83.8^{*}$ \\
\hline $\begin{array}{l}\text { Positive Diabetic: STZ + } \\
0.5 \mathrm{ml} \text { normal Saline }\end{array}$ & $0.21 \pm 0.91$ & $-94.02^{*}$ \\
\hline $\begin{array}{l}\text { Experimental 1: STZ + } \\
30 \mathrm{mg} / \mathrm{kg} \text {, leaf extract }\end{array}$ & $1.02 \pm 0.15^{*}$ & $-78.9^{* *}$ \\
\hline $\begin{array}{l}\text { Experimental 2: STZ + } \\
60 \mathrm{mg} / \mathrm{kg} \text { leaf extract }\end{array}$ & $0.53 \pm 0.26$ & $-7.02^{* *}$ \\
\hline $\begin{array}{l}\text { Experimental 3: STZ + } \\
120 \mathrm{mg} / \mathrm{kg} \text { leaf extract }\end{array}$ & $0.42 \pm 0.17$ & $-26.3^{* *}$ \\
\hline $\begin{array}{l}\text { Experimental 4: STZ + } \\
30 \mathrm{mg} / \mathrm{kg} \text { fruit extract }\end{array}$ & $1.34 \pm 0.11^{*}$ & $+135^{* *}$ \\
\hline $\begin{array}{l}\text { Experimental 5: STZ + } \\
60 \mathrm{mg} / \mathrm{kg} \text { fruit extract }\end{array}$ & $0.88 \pm 0.14^{*}$ & $+54.4^{* *}$ \\
\hline $\begin{array}{l}\text { Experimental 6: STZ + } \\
120 \mathrm{mg} / \mathrm{kg} \text { fruit extract }\end{array}$ & $1.42 \pm 1.17^{*}$ & $+149^{* *}$ \\
\hline
\end{tabular}

\section{DISCUSSION}

Despite the success of modern medicine in the clinical management of diabetes, utilizing dietary regimens, hypoglycemic drugs and exercise, these approaches have their limitations $(\underline{22})$. Medicinal plans are being

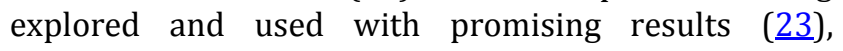
especially in Asia. In this context, the World Health Organization supports research plans toward the investigation and application of medicinal plants for use in the management of numerous diseases including diabetes. Since diabetes is one of the fastest growing metabolic diseases worldwide (2ㅡ), this study was designed to investigate the effects of the extract from the leaves and fruits of A. marina in a well known experimental model of diabetes as described in the Methods section earlier.

Consistent with previous research $(23, \underline{24})$, the findings of the current study clearly suggest the toxic and destructive effects of STZ (르), causing significant body weight losses and inducing diabetes in the treated rats (Tables 1-3). Also, the slightly lower rates of weight losses that was found for the Experimental groups that were treated with the leaves or fruits extract from $A$. marina indicate the mild protective effect of the extract against the STZ toxicity (Table 1). A more recent study (26) has shown similar effect for the extract of $A$. marina fruits in alloxon-induced diabetic rats. Another study (27) has reported that the alcohol extract of Mangrove leaves improved the hyperglycemia in alloxan-induced diabetic rats (27). The results of these studies are consistent with our findings and support the notion that therapeutic effects the A. marina extract against diabetes in animal models, and perhaps in humans are plausible.

There are many biologically active compounds in $A$. marina that have shown anti-diabetic effects, including glycopeptide compounds, terpenoids, alkaloids, flavonoids, phenols, peptides, amines, lipids, coumarins, saponins, ellagic acid and others $(\underline{28})$. The anti-diabetic mechanisms proposed for these compounds include glycogenic stimulation, liver glycolysis, potassium channel blockade in pancreatic beta cells, thereby enhancing the insulin release, and regulation of glucose uptake from the intestinal wall (29). The intraperitoneal injection of some flavonoids in STZ-induced diabetic rats can significantly reduce the serum glucose levels, while the same flavonoids do not have a significant effect on the serum glucose levels in healthy animals $(\underline{30})$. A clear mechanism for the differential effect has not been described or proposed yet.

It is conceivable that part of the hypoglycemic effects of flavonoids may come from the increased activity of hexokinase in the liver. This enzyme responds to changes of glucose levels in the liver by adjusting the glycogen synthesis (으). It can be argued that flavonoids may influence the number or synthetic activity the pancreatic beta cells due to their antioxidant properties thereby improving the symptoms of diabetes mellitus in animals and possibly humans. Support for this concept has been provided by a recent study, suggesting that the administration of flavonoids is likely to increases glucose uptake by fat, muscle and the liver tissues through a mechanism different from insulin ( $\underline{31}$ ). The administration of some polyphenols increases glucose transporters in muscle cells, which justifies the hypoglycemic effects in the experimental models of diabetes ( $\underline{32})$. Also, compounds containing saponins lower serum glucose and improve insulin secretion from the pancreatic beta cells ( $\underline{33})$. Alternatively, non-enzymatic antioxidant defense systems include ascorbic acid, alpha-tocopherol antioxidants present in A. marina. Antioxidant agents with different mechanisms neutralize reactive oxygen radicals and can thereby improve diabetes ( $\underline{34})$.

In light of the above discussion, it is plausible that the extract of the leaves and fruits of A. marina can exert its effects through more than a single mechanism. Putative mechanisms can include inhibition of glycogenolysis in the liver, enhancement of insulin release from the pancreas, as shown in this study (Table 3), and inhibition of glucose uptake from the intestinal wall. Although a specific mechanism for the hypoglycemic effects A. marina extract is not yet known, one or more of the following mechanisms may be involved: 
Increased consumption of glucose by cells, hence a decrease in serum glucose.

Proteins may bind the excess glucose molecules in the circulation, causing a decrease in its serum level.

Stimulation of some protein genes by certain components of the extract, causing enhanced protein synthesis that leads to more glucose binding in the blood and tissue.

The glucose-carrying proteins may be influenced by some active ingredients in the extract thus promoting glucose transport into cells.

Flavonoids may stimulate the pancreatic beta cells, enhancing the insulin release.

This study was not designed to provide specific answers to the above putative mechanisms; however, our results provided some preliminary clues, suggesting that the A. marina extract may contain agents, other than the known ones, that can act like insulin. Confirmation of the above putative mechanisms awaits further research on the medicinal properties of $A$. marina extract.

\section{CONCLUSION}

The results of this study suggest that the $A$. marina extract has beneficial properties for lowering blood glucose levels in experimentally induced diabetic rats. The biological and molecular mechanisms of this property have not yet been determined. We conclude that conducting future research can produce promising data leading to the elucidation of various mechanisms of action for the A. marina extract while introducing it to the medical community as a potential treatment against diabetes in humans.

\section{ACKNOWLEDGEMENTS}

We appreciate the faculty and staff at Jundishapur University of Medical Sciences, Ahvaz, for their support of this study.

\section{CONFLICT OF INTEREST}

The authors declare no conflict of interests inconducting this study.

\section{REFERENCES}

1. Guillausseau PJ, Meas T, Virally $M$, Laloi-Michelin $M$, Médeau V, Kevorkian JP. Abnormalities in insulin secretion in type 2 diabetes mellitus. Diabetes Metab. 2008;34Suppl 2:S43-48.

2. Abhijit M, Zaman S, Pramanick P, Banerjee K. Adaptive Efficiency of Avicennia marina seedlings to climate change induced salinity fluctuation. International Science Journal. 2014;12-132.

3. Liu Y, Tam NF, Yang JX ,Pi N, Wong MH, Ye ZH. Mixed heavy metals tolerance and radical oxygen loss in mangrove seedlings. Mar Pllout Bull. 2009;58(12):1843-1849.

4. Taghizadeh A, Danehkar A, Kamrani E, Mahmoudi B. Investigation the structure and dispersion of mangrove forest community in Sirik site in Hormozgan province . Iran Journal of Forest. 2009;1(1):25-34.[Persian]
5. Namazi R, Zabihollahi R, Behbahani M, RezaeiA. Inhibitory activity of Avicennia marina, a medicinal plant in persian folk Medicine against HIV and HSV. Iran J Pharm Res. 2013;12(2):435-443.

6. Feng Y, Li XM, Duan XY, Wany BG. Iridoidglucosides and flavones from The aerial Parts of Avicennia marina. Chemistry and Biodiversity. 2006;3(7):799-806.

7. Fauvel MT, Taoubi K,Gleye J, Fouraste I. Phenylpropanoid glycosides from Avicennia marina. Planta Medica.1993;59(4):387. Doi: 10.1055/s-2006-959711.

8. Ravikumar S, Inbaneson SJ, Suganthi P, Gnanadesigan M. In vitro antiplasmodial activity of ethanolic extracts of mangrove plants from South East coast of India against chloroquine-sensitive Plasmodium falciparum. Parasitol Res. 2011;108(4):873-878.

9. Romero MA, Wilson S, Blunden G, Yang MH, Cuervo AC, Bashir AK. Betaines in coastal plants. Biochemical systematics and Ecology. 1998;26(5):535-543.

10. Oku H, Baba S, Koga H, Takara K, Iwasaki H. Lipid composition of mangrove and its relevance to salt tolerance. J plant Res. 2003;116(1):37-45.

11. Al-Rehaily AJ, Alhowiriny TA, El-Tahir KE, Al-Taweel AM, Perveen S. Molecular mechanisms that underlie the sexual stimulant actions of Avicennia marina (Forsk.)Vierh. and Crocus sativus L. Pak J Pharm Sci. 2015;28(1):49-58.

12. Zamani Gandomani M, Forouzandeh Malati E. Evaluation of Protective Efficacy of Avicennia marina (Forsk.) Vierh Leaves against Complete Freund's Adjuvant-induced Arthritis in Wistar. Iran J Pharm Res. 2014;13(3):945951.

13. Momtazi-Borojeni AA, Behbahani M, Sadeghi-Aliabadi $\mathrm{H}$. Antiproliferative activity and apoptosis induction of crude extract and fractions of Avicennia marina. Iran J Basic Med Sci. 2013;16(11):1203-1208.

14. Zargari A. Pharmaceutical plants.Volum3.Tehran University Press. 1977;715-716. [Persian]

15. Song YX, Ma Q, Li J. A new aurone glycoside with antifungal activity from marine-derived fungus Penicillium sp. FJ-1. Zhongguo Zhong Yao Za Zhi. 2015;40(6):1097-1101.

16. Hamzevi A, Sadoughi SD, Rahbarian R. The effect of aqueous extract of Avicennia marina (Forsk.) Vierh. leaves on liver enzymes' activity, oxidative stress parameters and liver histopathology in male diabetic rat. Feyz. 2017; 21(4):305-316.

17. Esmaeili Sabzevar H, Rahbarian R, Saleh Moghadam M, Sadoughi SD. Effect of Aqueous Extract of Mangrove Leaves (Avicennia marina) on the Antioxidant Enzyme Activities of the Ovarian Tissue in Diabetic Rats. Journal of Torbat Heydariyeh University of Medical Sciences. 2017;5(1):32-41.

18. Garib Naseri MK,Yahyavi H. Spamolytic activity of piper nigrum fruit aqueous extract on rat none-pregnant uterus. IJPT. 2007;6:35-40.

19. Gonçalves RV, Novaes RD, Sarandy MM, Damasceno EM, da Matta SL, de Gouveia NM, Freitas MB, Espindola FS. $5 \alpha$-Dihydrotestosterone enhances wound healing in diabetic rats. Life Sci. 2016.pii: S0024-3205(16)30168-0.

20. Ali BH, Bashir AK. Toxicological studies on the leaves of Avicennia marina (Mangrove) in rats. Intl. Journal of Applied Toxicology: 1998:18(2);111-116. 
21. Musabayane CT, Tufts MA, Mapanga RF. Synergistic antihyperglycemic effects between plant-derived oleanolic acid and insulin in streptozotocin-induced diabetic rats. Ren Fail. 2010;32(7):832-839.

22. Casqueiro J, Casqueiro J, Alves C. Infections in patients with diabetes mellitus: A review of pathogenesis. Indian J Endocrinol Metab. 2012; 16(Suppl1): S27-S36.

23. Fehresti Sani M, Montasser Kouhsari S, Moradabadi L. Effects of three medicinal plants extracts in experimental diabetes: Antioxidant enzymes activities and plasma lipids profiles in comparison with metformin. Iran J Pharm Res. 2012;11(3):897-903.

24. Hami J, Kerachian MA, Karimi R, Haghir H, Sadr-NabaviA. Effects of streptozotocin-induced type 1 maternal diabetes on PI3K/AKT signaling pathway in the hippocampus of rat neonates. J Med Food. 2009;12(3):552-560.

25. Sen S, Roy M, Chakraborti AS. Ameliorative effects of glycyrrhizin on streptozotocin-induced diabetes in rats. J Pharm Pharmacol. 2011;63(2):287-296.

26. Aljaghthmi O, Heba H, Zeid IA. Bioactive Compounds Extracted from Mangrove Plants (Avicennia marina and Rhizophora mucronata): an Overview. Pathophysiology. 2018.

DOI: https://doi.org/10.1016/j.pathophys.2018.09.002

27. Babuselvam Babu M. Bioactivity of Avicennia marina and rhizophora mucronata for the management of diabetes mellitus. World Journal of Pharmaceutical Research. 2014;3(1):311-318.
28. Jung M, Park M, Lee HC, Kang YH, Kang ES, Kim SK. Antidiabetic agents form medicinal plants. Curr Med Chem. 2006;13(10):1203-1218.

29. Marles RJ.World Health Organization - Diabetes mellitus, Report of WHO study group. Journal of Bot Med .1996;1(3): 85-135.

30. Abdelmoaty MA, Ibrahim MA, Ahmed NS, Abdelaziz MA. Confirmatory studies on the antioxidant and antidiabetic effect of quercetin in rats. Indian J Clin Biochem. 2010;25(2):188-192.

31. Su HC, Hung LM, Chen JK. Resveratrol, a red wine antioxidant, possesses an insulin-like effect in streptozotocin-induced diabetic rats. Am J Physiol Endocrinol Metab. 2006; 2 90: E 1339-1346.

32. Chi TC, Chen WP, Chi TL, Kuo TF, Lee SS, Cheng JT, Su MJ. Phosphatidylinositol-3-kinase is involved in the antihyperglycemic effect induced by resveratrol in streptozotocin-induced diabetic rats. Life Sci. 2007;80:1713-1720.

33. Ferdinando G, Michael B. Schmidt AM, Oxidative stress and diabetic complications. Circ Res. 2010;107:10581070.

34. Oishi Y, Sakamoto T, Udagawa H, Taniguchi H, KobayashiHattori K, Ozawa Y, Takita T. Inhibition of increases in blood glucose and serum neutral fat by Momordicacharantia saponin fraction. Biosci Biotechnol Biochem. 2007;71:735-740. 